\title{
Bunker Suppliers Accreditation as Quality Assurance for Fuel Supplied to Ships Using E-Bunker Database Method
}

\author{
Eko Haryanto $^{1, a, *}$, Iqbal Fikri ${ }^{1, b}$ and Tribuana Galaxy ${ }^{1, c}$ \\ Statutory Division, Biro Klasifikasi Indonesia, Jakarta, Indonesia \\ a.eko.haryanto@bki.co.id,b.iqbal@bki.co.id,c.galaxy@bki.co.id \\ *corresponding author
}

Keywords: $\quad$ Accreditation scheme, bunker supplier, sulphur content, e-bunker database.

\begin{abstract}
International Maritime Organization (IMO) through MARPOL Convention Annex VI Regulation 14 and 18 stated that from 1 January 2020 Sulphur content restrictions of fuel supplied onboard ships shall not exceed $0.5 \% \mathrm{~m} / \mathrm{m}$. In Indonesia, the provisions of the Sulphur content in fuel are generally regulated by the Government through Peraturan Pemerintah no. 36 of 2004 Article 48 paragraph (5) and Peraturan Menteri ESDM No 07 of 2005 Article 33 paragraph (e). The aforementioned government regulations contain the provisions of the fuel specification limits, including the Sulphur content applied to manufacturers to the existing fuel distributor in Indonesia. However, that government regulation does not specifically regulate the quality of the marine fuel from bunker supplier to ships. Indonesian government will face the challenge of creating a system to standardize and monitor fuel quality especially Sulphur content to be used on board to comply with IMO sulfur content limitation. The initial proposed solution for these challenges is the establishment of bunker supplier accreditation scheme. The accreditation scheme will more effective by using e-bunkers database method. This initial proposed solution can help the government to standardize, document and monitor of fuel quality especially the Sulphur content of fuel supplied onboard. Bunker suppliers accreditation scheme using e-bunker database method is initial proposed solution to guarantee the fuel quality; especially the Sulphur content meets IMO regulations and manages a systematic data collection on the quality of marine fuel used in Indonesia.
\end{abstract}

\section{Introduction}

In order to reduce air pollution at sea, International Maritime Organization (IMO) through [1] Annex VI Regulation 14 and 18 stated that from 1 January 2020 Sulphur content restrictions of fuel supplied onboard ships shall not exceed $0.5 \% \mathrm{~m} / \mathrm{m}$. High Sulphur content in marine fuel can result in SOx emissions of adverse impacts on living things, such as: corrosion of metals, respiratory system irritation, degrading water quality, destroying crops and dissolving metals in the soil. Therefore, the reduction of Sulphur oxide emissions in the exhaust gas is expected to achieve 
improvement in air quality globally that have good impact for the life of living things in the world, especially in Indonesia.

Maintenance of fuel quality involves several parties, namely refineries as producers, bunker suppliers as distributors and ships as consumers. Refineries have important role to produce fuel that comply with standard, provide good storages and have good procedures in order to maintain the fuel's specification. In the distribution process, bunker supplier have to maintain the fuel quality by providing storage tanks and transfer systems that capable of maintaining fuel quality especially for sulfur content to meet the regulation's limitation. Eventually, ships as consumers are using Bunker Delivery Notes (BDN) as fuel quality documentation for checking when it is needed.

The quality controls for marine fuel delivered to the ships are using BDN. BDN basically represents the documentation of bunkering fuel information such as; fuel quantity and characteristic including Sulphur content delivered to the ships, port of bunkering, as well as name of fuel supplier [16]. This documentation is kept on board ships and accompanied by a representative sample of its fuel oil delivered.

In the regard of $0.5 \% \mathrm{~m} / \mathrm{m}$ Sulphur content regulation, the documentation of BDN will be beneficial for ship's owner, Administration, Port State Control (PSC) and other parties involved to record, control and ensure the quality of fuel oil delivered and used on-board ships. Furthermore, BDN only reflect single bunkering activity for a ship.

Since BDN is one of methods to document the fuel quality as well as its Sulphur content, therefore this paper propose initial solution that will be addressed to further develop the BDN into a marine fuel quality database. The discussion in this paper will be extended by also bringing together the Bunker Supplier Companies in order to register and give accreditation for fuel quality distributed in Indonesia. This accreditation is intended to be assuring the quality of bunkers supplied to ships thus can give protection to the fuel consumers and avoiding violations of the $0.5 \% \mathrm{~m} / \mathrm{m}$ Sulphur regulation.

\section{Fuel Quality and Availability}

\subsection{Fuel Availability Study by CE Delft}

CE Delft is one of the member in Non-Governmental Organization (NGO) IMO. CE Delft has conducted research related to the availability and quality of marine fuel in the world. The study was reported to IMO and used as a reference to the implementation of the regulation. CE Delft in conclusion states that the fuel requirement with Sulphur content $\leq 0.5 \% \mathrm{~m} / \mathrm{m}$ will be able to be fulfilled by refinery industries. [2]

CE Delft has developed the study by using 3 (three) main elements in order to assess the availability of marine fuel. The first element was estimating the demand for fuel consumption for 2020 based on the fuel consumption of ships in 2012. The second element was projecting the increase in consumption in line with the growth of energy demand. The last element was considering the possibility of using alternative solutions such as the Exhaust Gas Cleaning (EGR) system and the use Liquefied Natural Gas (LNG).[2]

This study was also developed based on these following 3 (three) main scenarios:

- $\quad$ "Base case" scenario with conditions of energy requirements and use of EGR and LNG in accordance with current conditions.

- "High case" scenario with conditions of high energy requirements whereas low EGR and LNG usage.

- $\quad$ Low case" scenarios with conditions that are opposed to high cases where low energy requirements and high EGR and LNG usage. 
Based on the above scenarios and assumptions, CE Delft projected the following fuel requirements:

Table 1: Fuel requirements projection

\begin{tabular}{|c|c|c|c|c|}
\hline \multirow{2}{*}{$\begin{array}{l}\text { Sulphur } \\
(\% \mathrm{~m} / \mathrm{m})\end{array}$} & \multicolumn{4}{|c|}{ Petroleum derived fuels } \\
\cline { 2 - 5 } & $<0.10 \%$ & $0.10 \%-0.50 \%$ & $>0.50 \%$ & $L N G$ \\
\cline { 2 - 5 } & 39 & 233 & 36 & 12 \\
\hline Base case & 38 & 290 & 14 & 12 \\
\hline High case & 33 & 198 & 38 & 13 \\
\hline Low case & 33 &
\end{tabular}

In relation to the need or demand in the above table, CE Delft has summarized the capacity of refineries globally as follows:

Table 2: Global refinery capacity

\begin{tabular}{|l|c|c|c|}
\hline \multirow{2}{*}{ Parameter } & 2012 & 2019 & Change \\
\cline { 2 - 4 } & \multicolumn{3}{|c|}{ Million tons per year } \\
\hline Crude Distillation & 4630 & 5020 & $+8 \%$ \\
\hline \multicolumn{4}{|c|}{ Light Oil Processing } \\
\hline Reforming & 610 & 626 & $+3 \%$ \\
\hline Isomerization & 94 & 122 & $+30 \%$ \\
\hline Alkylation/polymerization & 117 & 118 & $+1 \%$ \\
\hline \multicolumn{4}{|c|}{ Conversion } \\
\hline Coking & 312 & 421 & $+35 \%$ \\
\hline Catalytic cracking & 862 & 916 & $+6 \%$ \\
\hline Hydro cracking & 388 & 532 & $+37 \%$ \\
\hline Gasoline & 148 & 204 & $+38 \%$ \\
\hline Naphtha & 759 & 810 & $+7 \%$ \\
\hline Middle distillates & 1,109 & 1,306 & $+18 \%$ \\
\hline Heavy oil/residual fuel & 439 & 507 & $+15 \%$ \\
\hline
\end{tabular}

The main results of CE Delft study indicate that the refinery sectors have sufficient capacity of the required fuel in order to meet all of those scenarios. In addition, the required fuel with the quality of $<0.5 \% \mathrm{~m} / \mathrm{m}$ Sulphur content can be met by also taking into account other types of fuels such as; LPG, Kero Fuel, and others fuels with low or zero Sulphur content.

\subsection{Specification and Type of Marine Fuel}

\subsubsection{International Specification}

ISO 8217:2017 provide the specific requirements for fuels used in marine diesel engine as well as for boiler. The specification include the main criteria related to the application for MARPOL Annex VI such as: Sulphur content, fuel density, flash point, and so on. In general, this standard is distinguishing the marine fuels into 2 (two) main categories: distillate fuels and residual fuels. [3]. The distillate fuel is a general classification for one of the petroleum fractions produced in conventional distillation operations.[12] Whether the residual fuel is a complex blend of hydrocarbons derived from various refinery streams, usually residue, and can contain hydrogen sulfide and polycyclic aromatic hydrocarbons.[13]

Based on the ISO 8217:2017, the distillate fuel has lower Sulphur content than the residual. For instance, ISO $8217-D M X$ has $1 \% \mathrm{~m} / \mathrm{m}$ Sulphur content. In the Regulation side of view, IMO MARPOL Annex VI requires $0.5 \% \mathrm{~m} / \mathrm{m}$ as the maximum limit for global Sulphur for fuel used on- 
board ship. Therefore, the distillate fuel will have a bigger chance than residual fuel to meet the IMO global Sulphur cap regulation.

\subsubsection{National Specification}

Indonesian government throughout [4] on Standards and Quality (Specifications) of Fuel Marketed in Indonesia, provide 2 (two) kinds of marine fuel IFO (intermediete fuel oil) and Heavy Fuel Oil (HFO). IFO made from blending of HFO with Gas Oil or Marine Diesel Oil (MDO) to produce a range of specified viscosity.[14] Whether MFO is one type of fuel oil that can be used on diesel engines, especially those with greater weight. The MFO type is the residual fuel that is visible in a solid black color, and is viscous.[15]

The sulphur content in MFO and IFO can be summarized in table III below. From the specifications described from both tables it can be seen that the existing specification does not meet the Sulphur content regulation $\leq 0.5 \% \mathrm{~m} / \mathrm{m}$. National specification have too high Sulphur content. However, Table IV shows that IFO1 has maximal sulfur content lowest of the others.

Table 3: National specification standard

\begin{tabular}{|c|c|c|c|c|}
\hline \multirow{2}{*}{ Parameter } & \multicolumn{2}{|c|}{ IFO-1-\% (m/m) } & \multicolumn{2}{c|}{ IFO-2-\% (m/m) } \\
\cline { 2 - 5 } & $M I N$ & $M A X$ & $M I N$ & $M A X$ \\
\hline \multirow{4}{*}{$\begin{array}{c}\text { Shulphur } \\
\text { content }\end{array}$} & - & 3.50 & - & 4.00 \\
\cline { 2 - 5 } & \multicolumn{2}{|c|}{ MFO-1-\% (m/m) } & \multicolumn{2}{|c|}{ MFO-2-\% (m/m) } \\
\cline { 2 - 5 } & $M I N$ & $M A X$ & $M I N$ & MAX \\
\cline { 2 - 5 } & - & 4.50 & - & 5.00 \\
\hline
\end{tabular}

\subsubsection{PT Pertamina Specification}

PT. Pertamina as government-owned companies that focus on oil and gas industry has some fuel marine products that marketed in Indonesia. These fuels comply with [5] on Pertamina specification can be explained in table IV below. From the specifications described from Table IV can be seen that there is chance to be able to meet the Sulphur content regulation $\leq 0.5 \% \mathrm{~m} / \mathrm{m}$. Marine Diesel Fuel-1 has lowest maximal limit of Sulphur content. Some methods can be done as shown in the figure 1 below.

Table 4: Pertamina specification.

\begin{tabular}{|l|c|c|}
\hline \multirow{2}{*}{ Fuel Oil } & \multicolumn{2}{c|}{$\begin{array}{c}\text { Sulphur Content } \\
(\% \mathbf{~ m} / \mathbf{m})\end{array}$} \\
\cline { 2 - 3 } & MIN & MAX \\
\hline Minyak Bakar I (180cst) - Ignition Fuel Oil 1 & - & 3,5 \\
\hline Minyak Bakar I (180cst) - Ignition Fuel Oil 2 & - & 4,0 \\
\hline Marine Gas Oil - 5 & - & 3,5 \\
\hline Minyak Bakar II - Marine Fuel Oil 1 & - & 4,5 \\
\hline Minyak Bakar II - Marine Fuel Oil 2 & - & 5,0 \\
\hline
\end{tabular}




\begin{tabular}{|l|c|c|}
\hline \multirow{2}{*}{ Fuel Oil } & \multicolumn{2}{|c|}{$\begin{array}{c}\text { Sulphur Content } \\
(\mathbf{\%} \mathbf{m} / \mathbf{m})\end{array}$} \\
\cline { 2 - 3 } & $\boldsymbol{M I N}$ & $\boldsymbol{M A X}$ \\
\hline Marine Diesel Fuel - 1 & - & 1,5 \\
\hline Marine Diesel Fuel - 2 & - & 2,0 \\
\hline
\end{tabular}

\subsection{Initial Solution for Fulfilment of Regulation $0.5 \% \mathrm{~m} / \mathrm{m}$ Sulphur}

Based on [6] there are 2 (two) main methods that can be applied to meet the regulation of $0.5 \%$ $\mathrm{m} / \mathrm{m}$ Sulphur content limit on marine fuel, namely direct method and system modification. The direct method which is conducted by using fuel with specifications complies with the MARPOL Annex VI regulation. System modification propose the ship owner to implement or retrofit their ships by using additional system such as wet scrubber, dry scrubber, plasma to reduce the emitted Sulphur in the exhaust gas. Between the two methods, it is concluded that the only minor modifications required for ships are the use of low Sulphur fuel such as the use of distillate fuel, distillate fuel of the Ultra-Low Sulphur Fuel Oil (ULSFO) type, a new type of residual fuel named VLSFO-RM, and mixed fuel. One of mix fuel is ethanol-diesel that can reduce sulfur content about 20\%.[7] In detail the fulfillment process can be seen in the figure 1 below.

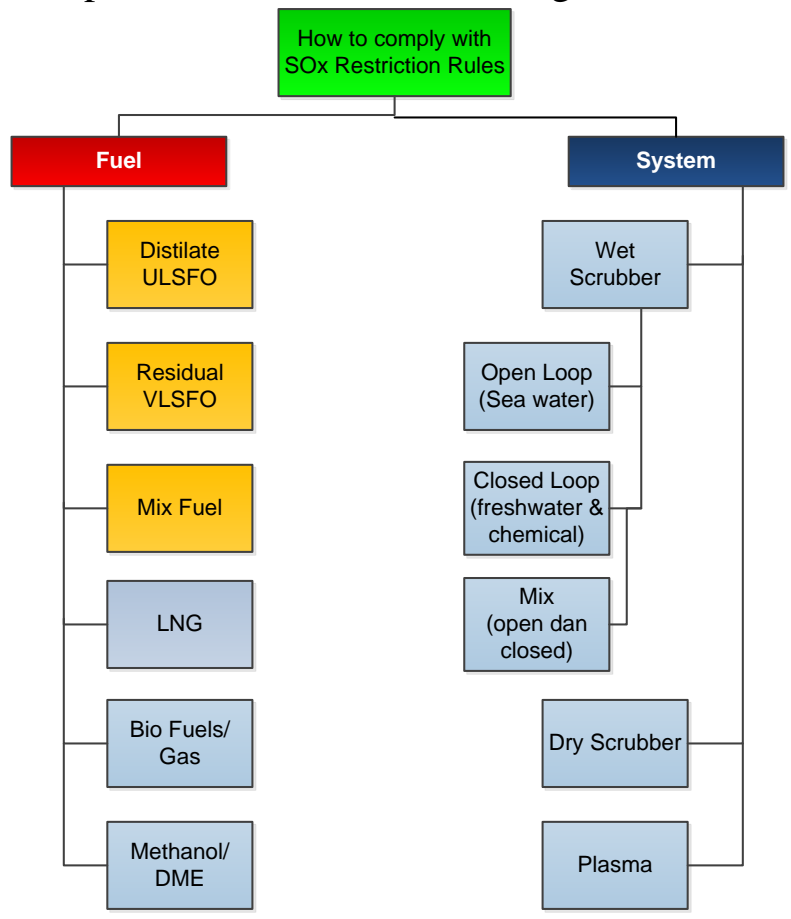

Figure 1: Sulphur content fulfilment process.

\subsection{Data Management using E-Database}

Data management using electronic system can make simply for data recording. The recorded data is collected to be electronic databases for data storing, recovering, and disposing. Electronic database system make these functions can be done efficiently.[8] Most electronic document management systems provide more effective management, support the quality system, support efficient storage, management and access to information, logging of the activity of the enterprise, optimization of business processes and automation, maximum reduction of paper documents. [9] 
The use of electronic databases is very effective and efficient when used in bunkering operational recording system. Bunkers suppliers are able to control their performance by monitoring the statistics of fuel quality that has been transferred to ships. Then with this recording system the ship is able to choose and determine the location and ability of the fuel station to be addressed. In addition, the government will get a database of marine fuel quality used by ships in the territorial waters. Thus, the government is able to determine the policies by referring to the database.[10]

\subsection{Data Management using E-Database}

Verification of fuel quality transferred to ships can be done through monitoring the bunkering process. Bunkering process monitoring is done in various systems as follows: [11]

- Bunker delivery notes;

A Bunker Delivery Note (BDN) is simple monitoring system. It has lowest investment but cannot be used to monitor emissions in a geographically delineated system.

- Tank sounding;

Tank sounding system needs low investment because majority of ships have tank sounding systems. There are 2 (two) means for monitoring emission, manual reading and automatic reading. Manual reading has low operational cost but may more data result in errors.

- Fuel flow meters;

Fuel flow meters system has highest potential accuracy by using suitable technology.

- Direct emissions monitoring.

in addition to being able to detect $\mathrm{SO} 2$ emissions Direct emissions monitoring can also detect other emissions.

\subsection{Challenges Facing IMO Sulphur Cap Regulation $0.5 \% \mathrm{~m} / \mathrm{m}$}

In general, there several parties involved in the marine fuels distribution chain in Indonesia, such as:

The distribution chain of marine fuels in Indonesia is carried out by three main parties called Manufacturers (PT Pertamina Persero) as commercial company, Distributors (Bunker Supplier Company) and Consumers (Ship owners). Roles and regulations for fuel quality of three main parties are shown in Table VI. From the description in the Table VI, it can be concluded that the Bunkers Supplier is the most appropriate party to describe the amount of fuel consumed by ships in Indonesia.

Table 5: The role of related parties in the distribution of marine fuel in Indonesia.

\begin{tabular}{|l|l|l|l|}
\hline \multicolumn{1}{|c|}{ Parameter } & fuel trading company & \multicolumn{1}{|c|}{ Bunker Supplier } & \multicolumn{1}{c|}{ Ships } \\
\hline \multicolumn{1}{|c|}{ Activity } & \multicolumn{1}{|c|}{ Fuel productions } & Distribute fuel to ships & \multicolumn{1}{c|}{ Consume fuel } \\
\hline Regulation for & PP No. 36 Tahun & MARPOL Annex VI & MARPOL Annex \\
Fuel Quality & 2004: & Reg. 14 dan 18 & VI Reg.22A \\
& Pasal 48 ayat (5) & & \\
& Permen ESDM 07 & & \\
& Tahun 2005: & & \\
& Pasal 33 ayat (e ) & & \\
\hline
\end{tabular}

The problems that arise come from the fuel distribution sector from producer to consumer described in the Table VII. Base on description in table VII can be concluded that there are 2 (two) 
main challenges to be faced. The first challenge is the need for fuel quality that distributed to ships. Then the second challenge is the need for fuel quality assurance from bunker supplier distributed to ship that comply with IMO Sulphur Cap $0.5 \% \mathrm{~m} / \mathrm{m}$.

There are two proposed solutions to face these challenges. First proposed solution is providing bunker supplier accreditation scheme that can be done effectively to assurance sulphur content comply with the regulation. Second proposed solution is providing good method to record all bunkering activity and arrange the data to be database that can be access easily by all bunkering parties.

Table 6: Indonesia challenges facing IMO sulphur cap regulation.

\begin{tabular}{|c|l|l|l|}
\hline No. & \multicolumn{1}{|c|}{ Parties } & \multicolumn{1}{|c|}{ Problems } & \multicolumn{1}{c|}{ Solutions } \\
\hline 1 & Refinery & $\begin{array}{l}\text { The number of marine fuels } \\
\text { produced does not represent } \\
\text { the amount of marine fuel } \\
\text { delivered to the vessel due to } \\
\text { the export and import } \\
\text { process. }\end{array}$ & $\begin{array}{l}\text { Record of the amount of } \\
\text { fuel delivered to the } \\
\text { vessel. }\end{array}$ \\
\hline 2 & Bunker Supplier & $\begin{array}{l}\text { There has been no guarantee } \\
\text { of the quality of distributed } \\
\text { marine fuel and the } \\
\text { dispersion of marine fuel } \\
\text { distribution procedures. }\end{array}$ & $\begin{array}{l}\text { Assurance of the quality } \\
\text { of marine fuel as well as } \\
\text { the distribution process } \\
\text { according to the standard } \\
\text { apply. }\end{array}$ \\
\hline 3 & Ships & $\begin{array}{l}\text { There has been no reporting } \\
\text { on the amount of fuel } \\
\text { consumed by the vessel to } \\
\text { the Government of } \\
\text { Indonesia. }\end{array}$ & $\begin{array}{l}\text { Data collection and } \\
\text { reporting the amount of } \\
\text { fuel consumed by the } \\
\text { vessel to the Government } \\
\text { of Indonesia. }\end{array}$ \\
\hline
\end{tabular}

\section{Bunker Supplier Accreditation Scheme}

The bunker supplier certification process consists of several stages including the initial certification process, the data processing and the periodical certification process. This scheme can make bunkering process become easier and simpler. By doing the following stages, bunker suppliers can do bunkering without having to do fuel testing on every bunkering process. Bunker suppliers report any bunkering activity through electronic reporting so that fuel quality data of each activity can be recorded in detail.

Detail process is described in the following schemes. Figure 2 show the Initial Certifications Process Scheme for bunker supplier. In this scheme there are two main step, first step is preassessment that contain reviewing process for bunker supplier manual and plan. Second step is field assessment for bunkering installations performance. In second step the surveyor get bunkering installations performance data to maintain marine fuel comply sulphur cap regulations. This performance data is used as reference to issue certificate.

\subsection{Initial Certifications Process Scheme}

Figure 2 show the Initial Certifications Process Scheme for bunker supplier. In this scheme there are two main step, first step is pre-assessment that contain reviewing process for bunker supplier manual and plan. Second step is field assessment for bunkering installations performance. In second step the surveyor get bunkering installations performance data to maintain marine fuel comply sulphur cap regulations. This performance data is used as reference to issue certificate. 


\subsection{Periodical Certifications Process Scheme}

Figure 3 show the Periodical Certifications Process Scheme to maintain bunkering installations. Periodical certification is the mean to maintain bunkering installation in order to stay on standard performance to comply sulphur content limits. Main step in this certification is field assessment. The result from this step will be used as reference to issue certificate.

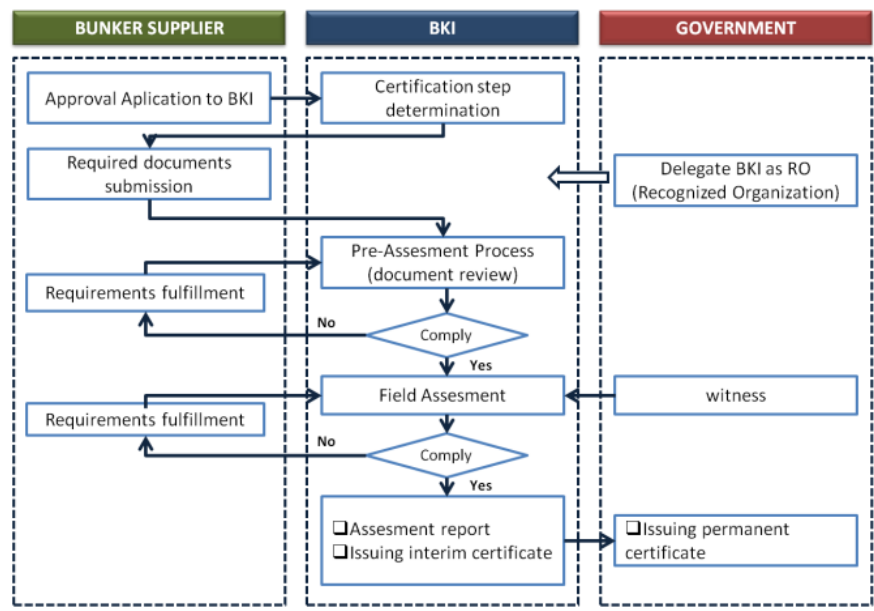

Figure 2: Initial Certifications Process Scheme

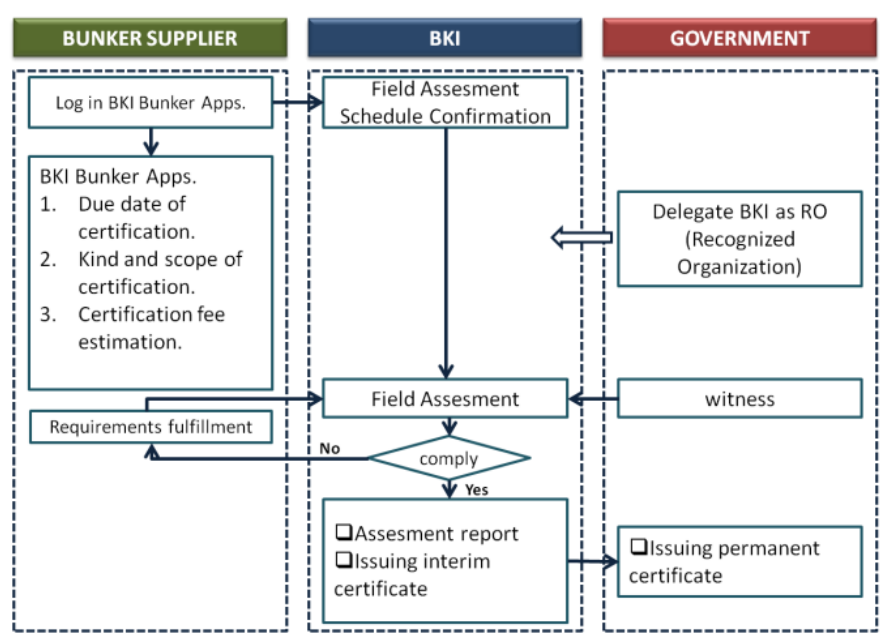

Figure 3: Periodical Certifications Process Scheme

\subsection{Bunkering Process Using E-Bunker Database Method}

E-Bunker Database is method to collect bunkering data efficiently. This method can speed up and make simpler bunkering process. Bunkering process using E-Bunker Database method consist 4 (four) main step as follow:

- Process 1 - Bunker supplier accreditation process conducted by Surveyor.

- Process 2 - Bunker supplier submit main specification data using E-Bunker system.

- Process 3 - Collect data of bunkering process by bunker supplier and ships owner.

- Process 4 - Report the main data of bunkering process to Government.

Four steps above can descript clearly trough Figure 4 below. 


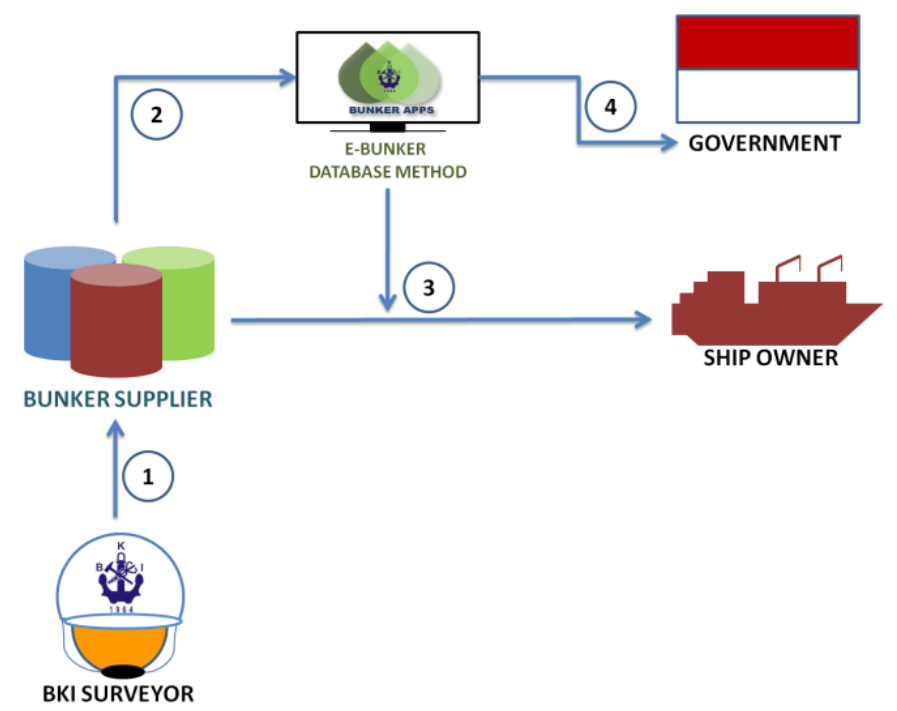

Figure 4: Fig. 4. Bunkering process using e-bunker database method.

In detail the process of bunkering data processing can be seen in the Figure 5 below:

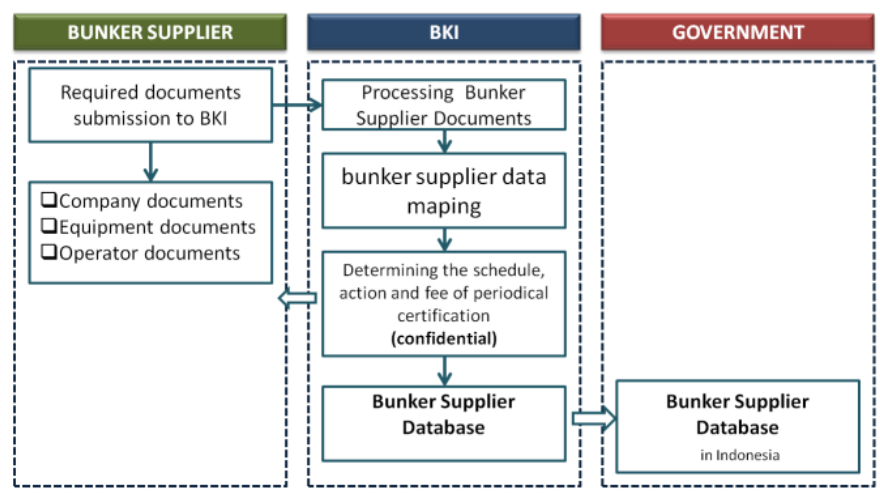

Figure 5: E-bunker database processing.

E-Bunker database process can be described in detail in 4 (four) steps as follow:

- Bunker supplier submit specification data using E-Bunker database system.

- E-Bunker system process the data (data mapping base on quality, area and the other factors).

- E-Bunker system determines the schedule, to do list for certification process.

- Mapped database to be submitted to Government.

\subsubsection{Benefit of using $\mathrm{E}-\mathrm{B}$ unker Database Method}

The application of E-Bunker Database method provides good benefits for the parties involved in bunkering activities, this benefit is described as follows :

- Benefits for Bunker Supplier :

Bunker supplier will get quality assurance from a recognized organization. Therefore bunker supplier can get trust from service users. Furthermore bunkering process becomes simpler and cheaper.

- Benefits for Ship owner : 
Ship owner can be sure that fuel quality has fulfilled the sulphur content of $0.5 \% \mathrm{~m} / \mathrm{m}$. This compliance can degrade the risk of detention abroad. This method can speed up bunkering process and reduce ship's operating costs.

- Benefits for Government :

By using E-Bunker database method Government will get a database supplier bunker that can be used as one of the trusted data reference in decision making related bunkering process. Furthermore government is easier to implement compliance IMO global sulphur regulation of $0.5 \% \mathrm{~m} / \mathrm{m}$. furthermore improving government performance as a flag state..

\section{Conclusions and Recommendations}

This study can be regarded as a proposed of possible solution to accommodate the regulatory framework of $0.5 \% \mathrm{~m} / \mathrm{m}$ Sulphur, marine fuel industries, as well as shipping industries and activities in Indonesia. Based on the literature study and discussion of this paper, it can be concluded that:

- Bunker supplier accreditation by using e-bunker database method is the most suitable initial proposed solutions to solve challenges and problems for marine fuel quality assurance and database in Indonesia.

- Bunker supplier is the most representative for marine fuel quality supplied onboard.

- Bunker supplier accreditation able to ensure marine fuel quality meets the regulation of sulfur content limits by certifying bunkering processes, equipment and operators with a certain period of validity.

- The use of electronic database systems capable for documenting actual data on fuel quality supplied onboard, speeding up and simplifying the process of fuel quality control as well as simplify the bunkering process..

\section{References}

[1] IMO, "MARPOL Convention Consolidated Edition 2017", IMO, 2017.

[2] IPIECA, "Refining impact of the IMO bunker fuel sulphur decision”, EGCSA Workshop, 2016.

[3] ISO 8217, "Petroleum products - Fuels (class F) - Specifications of marine fuels", ISO

[4] Direktorat Jenderal Minyak Bumi dan Gas, "Kepdirjen No: 14496K/14/DJM/2008 - Standar dan Mutu (Spesifikasi) Bahan Bakar Minyak Jenis Minyak Bakar yang Dipasarkan di Dalam Negeri”, Jakarta, 2008.

[5] PT. Pertamina (Persero) RU V, "Material Safety Data Sheet. Balikpapan”, Pertamina, 2012.

[6] D. Raitt, "ULSFO (0.10) and RM (VLSFO) Category-Potensial Future Trends”, Lloyd's Register Group, 2015.

[7] Yahuza and Dandakouta, "A Performance Review of Ethanol-Diesel Blended Fuel Samples in CompressionIgnition Engine”, Journal of Chemical Engineering \& Process Technology, 2015.

[8] Tanveer Haider Naqvi, "Use of Electronic Databases by Postgraduage Students and Research Scholars at GBPUAT Library, India”, Fiji National University, 2012.

[9] I.N.Burtylev*, K.V.Mokhun, Y.V. Bodnya, D.N. Yukhnevich," Development of Electronic Document Management Systems: Advantage and Efficiency", Institute of Economics and Information Technology, 2013.

[10] Maritime and Port Authority of Singapore, "Port of Singapore prepares for bunkering of the future", Corporate Communications Department, 2014.

[11] Jasper Faber, Dagmar Nelissen, Martine Smit, “Monitoring of bunker fuel consumption” Delft, CE Delft, 2013.

[12] U.S. Energy Information Administration (EIA), “Fuel Oil and Kerosene Sales 2016”, U.S. Department of Energy, 2017.

[13] U. S. OIL \& REFINING CO., “MATERIAL SAFETY DATA SHEET-Residual Fuel”, 2008.

[14] JISKOOT TM QUALITY SYSTEMS, “Fuel oil (bunker) blending An overview”, Jiskoot Limited, 2011.

[15] Syerly Klara, A.Husni Sitepu, Abd.Latief Had, "ANALISIS KOMBINASI MFO (MARINE FUEL OIL) DAN DIESEL OIL PADA MESIN DIESEL NANCHANG 2105 A-A3”, Jurusan Teknik Perkapalan - Fakultas Teknik, Universitas Hasanuddin, 2013.

[16] MARPOL Annex VI, "Regulations for the Prevention of Air Pollution from Ships", IMO, 2017. 